\title{
Tissue-Nonspecific Alkaline Phosphatase Acts Redundantly with PAP and NT5E to Generate Adenosine in the Dorsal Spinal Cord
}

\author{
Sarah E. Street, ${ }^{1}$ Nicholas J. Kramer, ${ }^{1}$ Paul L. Walsh, ${ }^{2}$ Bonnie Taylor-Blake, ${ }^{1}$ Manisha C. Yadav, ${ }^{3}$ Ian F. King, ${ }^{1}$ \\ Pirkko Vihko, ${ }^{4}$ R. Mark Wightman, ${ }^{2}$ José Luis Millán, ${ }^{3}$ and Mark J. Zylka ${ }^{1}$ \\ ${ }^{1}$ Department of Cell Biology and Physiology, and ${ }^{2}$ Department of Chemistry, Neuroscience Center, University of North Carolina, Chapel Hill, North Carolina \\ 27599, ${ }^{3}$ Sanford Children's Health Research Center, Sanford-Burnham Medical Research Institute, La Jolla, California 92037, and ${ }^{4}$ Department of Clinical \\ Medicine, Division of Clinical Chemistry, HUSLAB, University of Helsinki, FI-00014 Helsinki, Finland
}

Prostatic acid phosphatase (PAP) and ecto-5' -nucleotidase (NT5E) hydrolyze extracellular AMP to adenosine in dorsal root ganglia (DRG) neurons and in the dorsal spinal cord. Previously, we found that adenosine production was reduced, but not eliminated, in $\mathrm{Pap}^{-1-} / \mathrm{Nt} 5 \mathrm{e}^{-1-}$ double knock-out (dKO) mice, suggesting that a third AMP ectonucleotidase was present in these tissues. Here, we found that tissue-nonspecific alkaline phosphatase (TNAP, encoded by the Alpl gene) is expressed and functional in DRG neurons and spinal neurons. Using a cell-based assay, we found that TNAP rapidly hydrolyzed extracellular AMP and activated adenosine receptors. This activity was eliminated by MLS-0038949, a selective pharmacological inhibitor of TNAP. In addition, MLS-0038949 eliminated AMP hydrolysis in DRG and spinal lamina II of dKO mice. Using fast-scan-cyclic voltammetry, we found that adenosine was rapidly produced from AMP in spinal cord slices from dKO mice, but virtually no adenosine was produced in spinal cord slices from dKO mice treated with MLS-0038949. Last, we found that AMP inhibited excitatory neurotransmission via adenosine $\mathrm{A}_{1}$ receptor activation in spinal cord slices from wild-type, $P a p^{-1-}, N t 5 e^{-1-}$, and dKO mice, but failed to inhibit neurotransmission in slices from dKO mice treated with MLS0038949. These data suggest that triple elimination of TNAP, PAP, and NT5E is required to block AMP hydrolysis to adenosine in DRG neurons and dorsal spinal cord. Moreover, our data reveal that TNAP, PAP, and NT5E are the main AMP ectonucleotidases in primary somatosensory neurons and regulate physiology by metabolizing extracellular purine nucleotides.

\section{Introduction}

Ectonucleotidases regulate diverse physiological functions by hydrolyzing extracellular nucleotides such as ATP, ADP, and AMP (Picher et al., 2003; Zimmermann, 2006a; Schetinger et al., 2007; St Hilaire et al., 2011; Zylka, 2011). Recently, we identified two ectonucleotidases, prostatic acid phosphatase (PAP) and ecto-5' nucleotidase (NT5E), that are expressed in small-diameter, presumably nociceptive, dorsal root ganglia (DRG) neurons (Zylka et al., 2008; Sowa et al., 2010a). These enzymes hydrolyze AMP to adenosine in DRG neurons and their spinal axon terminals

\footnotetext{
Received Jan. 10, 2013; revised May 29, 2013; accepted June 4, 2013.

Author contributions: S.E.S., N.J.K., P.L.W., and M.J.Z. designed research; S.E.S., N.J.K., P.L.W., B.T.-B., and I.F.K. performed research; M.C.Y., P.V., R.M.W., and J.L.M. contributed unpublished reagents/analytic tools; S.E.S., N.J.K., P.L.W., B.T.-B., I.F.K., and M.J.Z. analyzed data; S.E.S. and M.J.Z. wrote the paper.

This work was supported by the National Institute of Neurological Disorders and Stroke-National Institutes of Health (Grant \#R01NS067688 to M.J.Z.), the National Institute of Dental and Craniofacial Research-National Institutes of Health (Grant \#R01 DE012889 to J.L.M.), and the National Institutes of Health (Grant \#R01NS038879 to R.M.W.). The In Situ Hybridization Core is funded by the National Institute of Neurological Disorders and StrokeNational Institutes of Health (Grant \#P30NS045892) and the National Institute of Child Health and Human Development-National Institutes of Health (P3OHD03110). We thank Megumi Aita for performing in situ hybridization and Brittany Wright for help with perfusion of mice.

The authors declare no competing financial interests.

Correspondence should be addressed to Mark J. Zylka, Department of Cell Biology and Physiology, UNC Neuroscience Center, University of North Carolina, CB \#7545, Chapel Hill, NC 27599. E-mail: zylka@med.unc.edu.

DOI:10.1523/JNEUROSCI.0133-13.2013

Copyright $\odot 2013$ the authors $\quad 0270-6474 / 13 / 3311314-09 \$ 15.00 / 0$
}

(Zylka et al., 2008; Sowa et al., 2010a). In addition, PAP and NT5E inhibit excitatory neurotransmission in the dorsal spinal cord and inhibit nociceptive responses at the behavioral level by acting through the adenosine $A_{1}$ receptor $\left(A_{1} R\right.$; Sowa et al., 2009; Sowa et al., 2010b; Street et al., 2011). Our research thus revealed roles for PAP and NT5E in reducing pain-related physiological and behavioral responses. Intriguingly, we also found that genetic deletion of PAP and NT5E using $\mathrm{Pap}^{-1-} / \mathrm{N} t 5 \mathrm{e}^{-1-}$ double knock-out (dKO) mice reduced, but did not eliminate, the production of adenosine from extracellular AMP, suggesting that at least one additional AMP ectonucleotidase was present in DRG neurons and spinal cord (Street et al., 2011).

In this study, we sought to ascertain the molecular identity of this third AMP ectonucleotidase. Using multiple approaches, including histochemistry, fast-scan-cyclic voltammetry (FSCV), and electrophysiology, we found that tissue-nonspecific alkaline phosphatase (TNAP; also known as liver/bone/kidney alkaline phosphatase) is this third enzyme. TNAP is an extracellularly active, glycophosphatidylinositol-anchored membrane protein that hydrolyzes several different molecules at physiological (neutral) and alkaline $\mathrm{pH}$, including nucleotides (Scheibe et al., 2000; Zimmermann, 2006b; Ciancaglini et al., 2010), pyridoxal-5' phosphate (the active form of vitamin $\mathrm{B}_{6}$ ) and inorganic pyrophosphate (Millán, 2006a). Inorganic pyrophosphate is a potent bone mineralization inhibitor and accumulates in TNAP- 
deficient mice and humans. This accumulation impairs bone mineralization and causes a rare, painful, and sometimes fatal disease called hypophosphatasia (Millán, 2006a; Mornet, 2007; Whyte et al., 2012).

TNAP is also widely expressed in the brain and developing spinal cord (Narisawa et al., 1994; MacGregor et al., 1995; Fonta et al., 2004; Langer et al., 2008), suggesting a role for this enzyme in the CNS. Indeed, Tnap ${ }^{-1-}$ (also referred to as $A l p l^{-1-}$ ) mice develop seizures by 2 weeks of age and then die 1-2 d later (Waymire et al., 1995; Narisawa et al., 1997). Children presenting with the most severe cases of hypophosphatasia may also manifest seizures caused by the affected metabolism of vitamin $B_{6}$ (Millán, 2006b; Mornet, 2007; Whyte et al., 2012).

TNAP also hydrolyzes extracellular ATP to promote the axonal growth of hippocampal neurons (Díez-Zaera et al., 2011) and TNAP can redundantly serve as a source of extracellular adenosine in the hippocampus when NT5E is deleted (Zhang et al., 2012). TNAP can thus regulate neuronal functions by metabolizing nucleotides. Here, we unexpectedly discovered a triple redundant role for TNAP, PAP, and NT5E in rapidly generating adenosine and inhibiting excitatory neurotransmission between primary somatosensory neurons and spinal neurons. Our present study, combined with our previous work (referenced above), firmly establishes that TNAP, PAP, and NT5E metabolize extracellular nucleotides in the somatosensory system.

\section{Materials and Methods}

Animals. All procedures involving vertebrate animals were approved by the institutional animal care and use committee at the University of North Carolina at Chapel Hill. Mice were raised under a 12:12 light:dark cycle and used during the light phase. C57BL/6 mice were purchased from The Jackson Laboratory or bred inhouse from C57BL/6J stock.

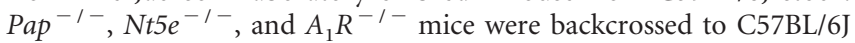
mice for $>10$ generations (Thompson et al., 2004; Vihko et al., 2005; Wu et al., 2005; Zylka et al., 2008). Tnap ${ }^{-1-}$ mice were maintained on a 12.5\% C57BL/6/87.5\% 129J background (Narisawa et al., 1997; Yadav et al., 2012). dKO mice were generated by breeding backcrossed $N t 5 e^{-1-}$ and $\mathrm{Pap}^{-1-}$ mice.

Enzyme histochemistry. Tissue was dissected from adult male mice (6-12 weeks old) and immersion fixed in $4 \%$ paraformaldehyde, $0.1 \%$ phosphate buffer, $\mathrm{pH} 7.4$, at $4^{\circ} \mathrm{C}$. Tissue was then cryoprotected in $30 \%$ sucrose, $0.1 \mathrm{~m}$ phosphate buffer, $\mathrm{pH} 7.3$, at $4^{\circ} \mathrm{C}$ for at least $24 \mathrm{~h}$. DRG and spinal cord were sectioned (20 and $30 \mu \mathrm{m}$ thick, respectively) on a cryostat and collected on Superfrost Plus slides (DRG) or as free-floating sections (spinal cord). Because Tnap ${ }^{-1-}$ mice die shortly ( $\sim 2$ weeks) after birth (Narisawa et al., 1997), AMP histochemistry was performed with $11 \mathrm{~d}$-old wild-type (WT) and Tnap ${ }^{-1-}$ mice (littermates). These young mice were perfused with $4 \%$ paraformaldehyde, $0.1 \%$ phosphate buffer, $\mathrm{pH} 7.4$, and then the entire spinal column was then dissected, cryoprotected, and sectioned ( $24 \mu \mathrm{m}$ thick) on a cryostat and collected on Superfrost Plus slides.

For alkaline phosphatase histochemistry, lumbar DRG and spinal cord sections were incubated in a substrate solution containing $1 \mu \mathrm{l} / \mathrm{ml} \mathrm{ni-}$ troblue tetrazolium (NBT; $37.5 \mathrm{mg} / \mathrm{ml}$ in $50 \%$ dimethylformamide; Fisher Scientific) and $1 \mu \mathrm{l} / \mathrm{ml}$ 5-bromo-4-chloro-3-indolyl phosphate, 4-toluidine salt (BCIP; $50 \mathrm{mg} / \mathrm{ml}$ in 100\% dimethylformamide; Roche) in $100 \mathrm{~mm}$ Tris, $\mathrm{pH} 8.5,50 \mathrm{~mm} \mathrm{MgCl}_{2}, 100 \mathrm{~mm} \mathrm{NaCl}$, and $0.1 \%$ Tween $20 \pm 5 \mathrm{~mm}$ levamisole. DRG sections were incubated for $90 \mathrm{~min}$; spinal cord sections were incubated from $40 \mathrm{~min}$ to $2 \mathrm{~h}$.

AMP histochemistry was performed as described previously (Zylka et al., 2008). Briefly, 1 mM AMP (DRG and HEK293 cells) and 3 mM AMP (spinal cord) were used as substrate in Tris-maleate buffer containing 20 $\mathrm{mm} \mathrm{MgCl}, \mathrm{pH} 7.0$ or 8.5 , with $2.4 \mathrm{~mm}$ lead nitrate. Where indicated, we included $5 \mathrm{~mm}$ levamisole or $20 \mathrm{~mm} \mathrm{~L}$-tartrate and $10 \mu \mathrm{M} \alpha \beta$-me-ADP for rinse and incubation steps. Quantification of staining intensity was performed using ImageJ. A rectangle was drawn over lamina II or a subset of
DRG neurons and the mean gray scale (a measure of pixel intensity) was calculated from 6 to 10 images from each genotype and averaged. To make the numbers more intuitive to the reader, we took the inverse of the mean gray scale and multiplied by 1000 so that larger numbers corresponded to darker staining, as described previously (Street et al., 2011).

In situ hybridization. We generated a plasmid for sense and antisense riboprobe synthesis by digesting a mouse TNAP I.M.A.G.E clone (6807509) with EcoRI and BamHI, and then subcloned the resulting 1190 bp fragment into pBS-KS(+). In situ hybridization with digoxigenin-labeled riboprobes $(1 \mu \mathrm{g} / \mathrm{ml})$ was performed as described previously (Dong et al., 2001). Sections were mounted in aqueous mounting medium (DAKO). Images were acquired with a Zeiss Axioskop and Olympus DP-71 camera.

Cell culture. HEK293 cells were grown on polylysine-coated glassbottom culture dishes (P35G-0-10-C; MatTek) or on coverslips in DMEM containing $10 \%$ fetal bovine serum, 100 units $/ \mathrm{ml}$ penicillin, and $100 \mu \mathrm{g} / \mathrm{ml}$ streptomycin. Cells were transfected with Lipofectamine Plus (Invitrogen) in DMEM containing 1\% fetal bovine serum, which was replaced with fresh growth medium after $4 \mathrm{~h}$. The total amount of DNA per transfection was adjusted to $1 \mu \mathrm{g}$ by adding pcDNA3.1 $(+)$; $100 \mathrm{ng}$ of pCS-Venus was also included to identify transfected cells. A full-length mouse TNAP expression construct was generated by digesting I.M.A.G.E clone 6807509 with EcoRI and NotI and then subcloning this fragment into pcDNA3.1 using the same restriction sites. This construct was used for histochemical and calcium imaging experiments. Cells were fixed $\sim 24 \mathrm{~h}$ after transfection.

Calcium imaging. Calcium imaging experiments using the human $\mathrm{A}_{2 \mathrm{~B}}$ adenosine receptor and chimeric Gqs plasmids were performed as described previously (Rittiner et al., 2012). Twenty-four hours after transfection, HEK293 cells were washed and loaded with $2 \mu \mathrm{M}$ Fura-2 AM (F1221; Invitrogen) and 0.02\% Pluronic F-127 (P3000-MP; Invitrogen) in assay buffer. Cells were then washed three times in assay buffer and incubated for $30 \mathrm{~min}$ before imaging on a Nikon Eclipse Ti microscope. A Sutter DG-4 light source (excitation $340 \mathrm{~nm} / 380 \mathrm{~nm}$; emission $510 \mathrm{~nm}$ ) and Andor Clara CCD camera were used to image calcium responses. After $40 \mathrm{~s}$ of baseline imaging, assay buffer was removed by gentle aspiration and replaced with assay buffer containing agonist (adenosine or AMP). Area under the curve values were calculated using the $60 \mathrm{~s}$ time period after agonist addition relative to baseline fluorescence ratio on a cell-by-cell basis and then averaged over all cells for a given condition.

Slice preparation. Transverse ( $800-900 \mu \mathrm{m}$, used in field recordings) and sagittal ( $400 \mu \mathrm{m}$, used in FSCV experiments) slices were prepared as described previously (Street et al., 2011). Briefly, spinal cords from 1- to 2-month-old mice were dissected and sectioned on a Vibratome 3000EP at $4^{\circ}$ in buffer containing the following in mM: $87 \mathrm{NaCl}, 2.5 \mathrm{KCl}, 1.25$ $\mathrm{NaH}_{2} \mathrm{PO}_{4}, 26 \mathrm{NaHCO}_{3}, 75$ sucrose, 10 glucose, 1.5 ascorbic acid, 0.5 $\mathrm{CaCl}_{2}$, and $7 \mathrm{MgCl}_{2}$. The slices were then incubated for $45 \mathrm{~min}$ at $37^{\circ} \mathrm{C}$ and then at room temperature in artificial CSF containing the following (in mM): $125 \mathrm{NaCl}, 2.5 \mathrm{KCl}, 1.25 \mathrm{NaH}_{2} \mathrm{PO}_{4}, 26 \mathrm{NaHCO}_{3}, 25$ glucose, 2.5 $\mathrm{CaCl}_{2}, 1.5 \mathrm{MgCl}_{2}$. All solutions were bubbled with $95 \% \mathrm{O}_{2} / 5 \% \mathrm{CO}_{2}$ for the duration of the dissection and incubation steps.

FSCV. FSCV experiments were performed as described previously (Street et al., 2011). Briefly, disk-shaped carbon-fiber microelectrodes were placed in sagittal mouse spinal cord slices. The electrode's potential was held at $-0.4 \mathrm{~V}$ between scans and was ramped from $-0.4 \mathrm{~V}$ to $1.5 \mathrm{~V}$ at a scan rate of $400 \mathrm{~V} / \mathrm{s}$ every $100 \mathrm{~ms}$. The peak at $1.0 \mathrm{~V}$ was used to quantify adenosine concentration. FSCV data were collected with a custom LABVIEW program, Tar Heel CV, and were viewed in the form of color plots with sequentially stacked cyclic voltammograms shown over time (abscissa) that were plotted against the electrode potential displaced on the ordinate where the switching potential $(1.5 \mathrm{~V})$ was in the middle. Current was displayed in false color, with oxidative currents being shown in green and reductive currents being shown in blue and black. These current traces were converted to concentration from calibrations performed in a flow injection apparatus in which adenosine (1-10 $\mu \mathrm{M})$ was introduced to the electrode surface.

To measure adenosine production in lamina II, AMP was pressure ejected 5 times at 5 min intervals with a Picospritzer III (Parker Instrumentation) for $1 \mathrm{~s}$ at $20 \mathrm{psi}$ from a micropipette inserted into the tissue 
$\sim 100 \mu \mathrm{m}$ away from the carbon-fiber microelectrode. AMP (09130; Fluka) was freshly prepared before each experiment.

Field potential recordings. Transverse spinal cord slices containing one dorsal root were placed in the recording chamber and field potential recordings were performed as described previously (Street et al., 2011). Briefly, a borosilicate glass recording electrode with a tip resistance of 1-2 $\mathrm{M} \Omega$ was placed in lamina II to record field potentials evoked by dorsal root stimulation. The dorsal root was stimulated with a suction electrode for $0.5 \mathrm{~ms}$ at 5 times the intensity needed to evoke a maximal response. The root was stimulated once every $10 \mathrm{~s}(0.1 \mathrm{~Hz})$ and every 6 signals were averaged to give a single point for every minute of recording. The resulting signals were filtered at 1 $\mathrm{kHz}$, amplified 1000 times with a Multiclamp $700 \mathrm{~B}$ amplifier, captured at $10 \mathrm{kHz}$ with an Axon Digidata 1440A, and analyzed using pClamp 10 software (Molecular Devices). AMP $(250 \mu \mathrm{M})$ was bath applied after $5 \mathrm{~min}$ of baseline recording, washed off for $5 \mathrm{~min}$, and then adenosine $(250 \mu \mathrm{M})$ was bath applied to confirm that the A $\delta$ potential was sensitive to adenosine. One experiment was performed per slice.

Quantitative RT-PCR. Total RNA was prepared from DRG of adult mice using TRIzol reagent (Invitrogen). First-strand cDNA was synthesized using the Superscript III reverse transcriptase kit (Invitrogen). Quantitative RT-PCR was performed with SYBR Green detection (Invitrogen Invitrogen) using a Rotorgene 3000 thermal cycler (Corbett Research) and Rotorgene software (version 6.0). Expression of Tnap $(A l p l)$ was quantified with primers spanning the ninth intron $\left(5^{\prime} \mathrm{CT}\right.$ GACTGACCCTTCGCTCTC3', 5'TCATGATGTCCGTGGTCAAT3') using kidney cDNA as a positive control. Tnap expression was normalized to levels of $A c t b$ for each sample (primers spanned the first intron of $A c t b: 5^{\prime} \mathrm{CA}$ GCTTCTTTGCAGCTCCTT3', 5'CACGATGGAGGGGAATACAG3').

Statistical tests. Statistical analysis was performed using Microsoft Excel and GraphPad Prism software. All data are shown as means \pm SE.

\section{Results}

\section{TNAP is widely expressed in DRG neurons and spinal} cord neurons

Using a quantitative electrochemical technique (FSCV), we previously found that genetic deletion of PAP and NT5E using dKO mice reduced, but did not eliminate, hydrolysis of AMP to adenosine in dorsal spinal cord at physiological (neutral) $\mathrm{pH}$ (Street et al., 2011). In contrast, essentially no adenosine was generated in $\mathrm{dKO}$ mice at $\mathrm{pH}$ 5.6. These data collectively suggested that at least one additional AMP hydrolytic enzyme was present and that this enzyme was active at neutral but not acidic $\mathrm{pH}$. Alkaline phosphatases can dephosphorylate ATP, ADP, and AMP (Zimmermann, 2006b; Ciancaglini et al., 2010), leading us to hypothesize that an alkaline phosphatase might generate adenosine in adult spinal cord.

To determine whether an alkaline phosphatase was present in DRG and spinal cord, we performed NBT/BCIP histochemistry at an alkaline $\mathrm{pH}, \mathrm{pH} 8.5$, with tissues from WT, $\mathrm{Pap}^{-1-}$, $N t 5 e^{-1-}$, and $\mathrm{dKO}$ adult mice ( $n=3$ for each genotype). We found that BCIP was hydrolyzed in virtually all DRG neurons (Fig. $1 A-D$ ) and throughout the spinal cord gray matter (Fig. $2 A-D)$ in all four genotypes. The nonselective alkaline phospha- tase inhibitor levamisole abolished staining in DRG from all four genotypes (Fig. $1 E-H$ ) and in spinal cord from $\mathrm{Pap}^{-1-}$ and $\mathrm{dKO}$ mice (Fig. 2F, $H$ ), indicating that an alkaline phosphatase was indeed present in these tissues. Levamisole did not inhibit NBT/BCIP histochemical staining in lamina II of WT or $\mathrm{Nt}^{-e^{-/-}}$mice (Fig. $2 E, G)$. This residual staining clearly originated from PAP, because staining was abolished in $\mathrm{Pap}^{-1-}$ and dKO mice (Fig. $2 F, H$ ). Although PAP is classified as an "acid phosphatase," we found that PAP could hydrolyze a commonly used substrate of alkaline phosphatases, BCIP. Further, our data indicate that PAP is also active at alkaline $\mathrm{pH}$ values, as was shown previously (Van Etten, 1982).

In the mouse, there are four genes that encode functional alkaline phosphatase enzymes (Millán, 2006b); of these, TNAP was previously found to be expressed in embryonic spinal cord (Narisawa et al., 1994; MacGregor et al., 1995). To determine whether TNAP was expressed in adult DRG and spinal cord, we performed in situ hybridization with TNAP-specific riboprobes. We found that antisense riboprobes against TNAP labeled all DRG neurons and neurons throughout spinal cord gray matter (Fig. $3 A, C$ ). In contrast, the sense (control) probes against TNAP only showed background staining (Fig. $3 B, D$ ). These data indicate that TNAP is expressed broadly in primary sensory neurons and spinal neurons. Given that TNAP is expressed and active (see below) in most if not all DRG neurons, TNAP is likely present in all sensory neuron subtypes.

\section{TNAP rapidly hydrolyzes extracellular AMP to adenosine in live cells}

TNAP can dephosphorylate a broad spectrum of substrates, including nucleotides such as ATP, ADP, and AMP (Zimmermann, 2006b; Ciancaglini et al., 2010). To determine whether TNAP can dephos- 


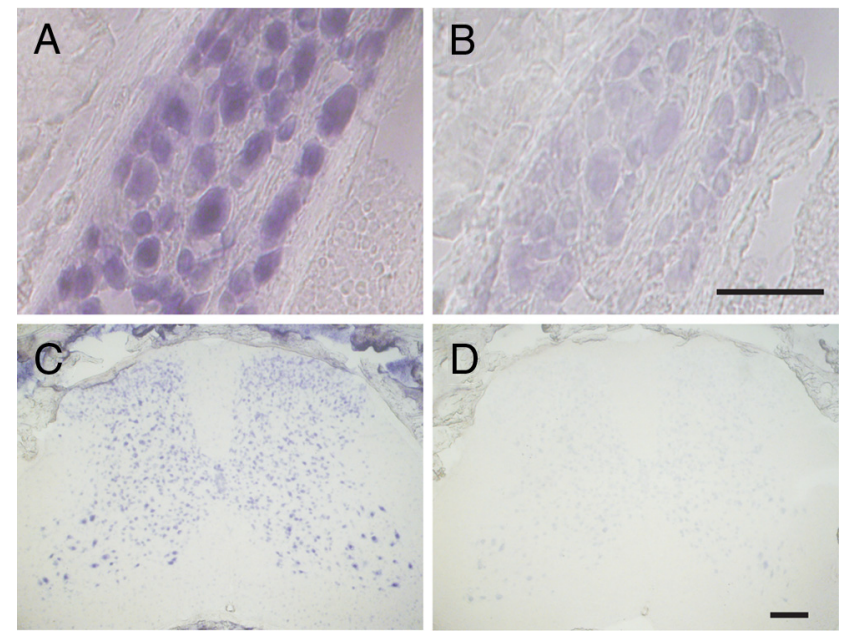

Figure 3. TNAP is expressed in DRG and spinal cord neurons. In situ hybridization of adult mouse lumbar DRG $(\boldsymbol{A}, \boldsymbol{B})$ and spinal cord $(\boldsymbol{C}, \boldsymbol{D})$ with antisense $(\boldsymbol{A}, \boldsymbol{C})$ and sense $(\boldsymbol{B}, \boldsymbol{D})$ TNAP riboprobes. Scale bars: $\boldsymbol{B}, 75 \mu \mathrm{m} ; \boldsymbol{D}, 250 \mu \mathrm{m}$.

phorylate AMP in a cellular context, we transfected HEK293 cells with a mouse TNAP expression construct and then performed AMP histochemistry. We found that TNAP-transfected cells were intensely stained when AMP was used as substrate at $\mathrm{pH} 8.5$, whereas HEK293 cells transfected with empty vector were unstained (Fig. $4 A, B)$. These data indicate that TNAP can dephosphorylate AMP when expressed in cells.

To determine whether TNAP can hydrolyze AMP and activate adenosine receptors in live cells, we used a cell-based assay that links the $\mathrm{G}_{\mathrm{s}}$-coupled $\mathrm{A}_{2 \mathrm{~B}}$ adenosine receptor $\left(\mathrm{A}_{2 \mathrm{~B}} \mathrm{R}\right)$ to phospholipase $\mathrm{C}$ and calcium mobilization (Rittiner et al., 2012). Adenosine rapidly activates $A_{2 B} R$ in this assay, whereas AMP does not activate $A_{2 B} R$ directly (AMP only activates $A_{2 B} R$ if cells are also cotransfected with an AMP ectonucleotidase; Rittiner et al., 2012). Therefore, we transfected HEK293 cells with a chimeric G-protein (Gqs), human $\mathrm{A}_{2 \mathrm{~B}} \mathrm{R}$, and TNAP and then stimulated these cells with either adenosine or AMP (each at $1 \mathrm{mM}$ ). We found that adenosine and AMP both induced a rapid onset calcium response in TNAP-transfected cells (Fig. 4C,D; cotransfected cells were identified using a Venus expression plasmid, data not shown). AMP did not evoke a calcium response in cells lacking $\mathrm{A}_{2 \mathrm{~B}} \mathrm{R}$ (no receptor controls that were transfected with Gqs and TNAP; Fig. 4C,D).

In addition, the TNAP-specific inhibitor MLS-0038949 (Dahl et al., 2009; Sergienko et al., 2009) blocked the rapid onset calcium response to AMP but not to adenosine in TNAP-transfected cells (Fig. 4E, F). These data indicate that TNAP can rapidly hydrolyze extracellular AMP and activate adenosine receptors in live cells. MLS-0038949 did not alter calcium responses to adenosine, thus ruling out the possibility that MLS-0038949 blocks $A_{2 B} R$, interferes with steps downstream of receptor signaling, or compromises cell health.

\section{TNAP, PAP, and NT5E account for nearly all of the AMP ectonucleotidase activity in DRG and spinal cord}

Next, we performed AMP histochemistry in the absence or presence of MLS-0038949 to determine whether TNAP participated in hydrolyzing AMP in adult DRG and spinal cord. Relative to WT mice, AMP histochemical staining was reduced in DRG sections from $\mathrm{dKO}$ mice at $\mathrm{pH} 7.0$ and 8.5, although pronounced membrane staining remained at both $\mathrm{pH}$ values (Fig.
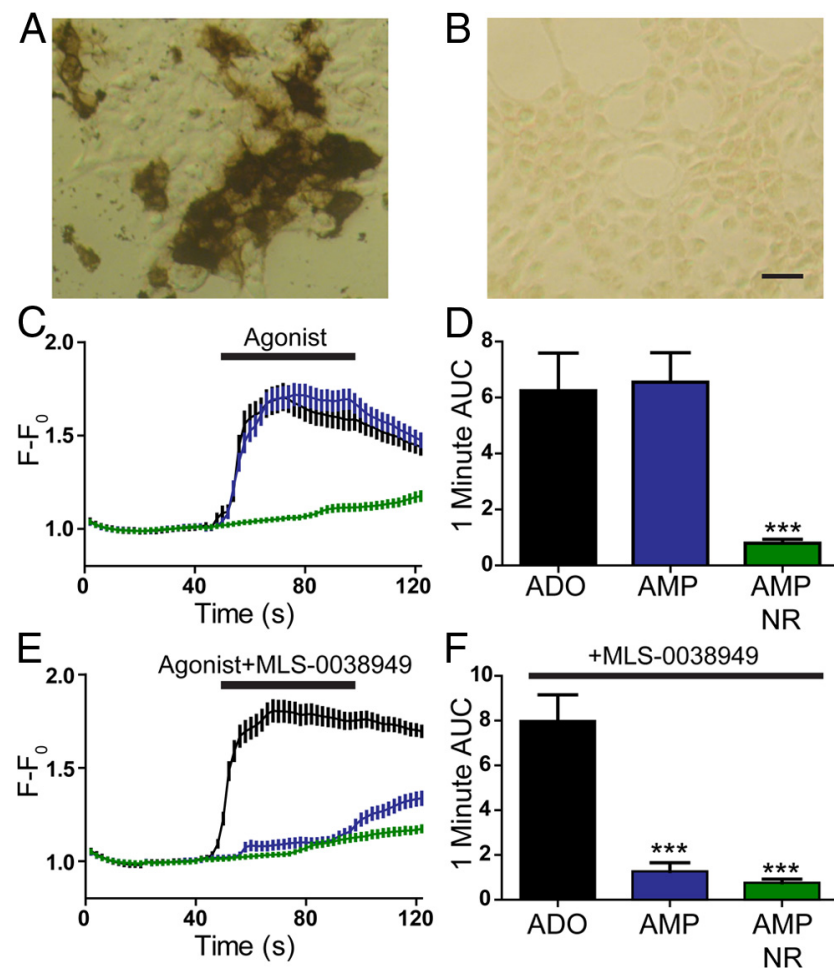

Figure 4. TNAP rapidly hydrolyzes extracellular AMP to adenosine in a cell-based assay and is inhibited by MLS-0038949. A, B, HEK293 cells transiently transfected with mouse TNAP $(\boldsymbol{A})$ or empty expression vector $(\boldsymbol{B})$ were stained using AMP histochemistry. The AMP concentration was $3 \mathrm{~mm}$. Scale bar, $50 \mu \mathrm{m}$. $\mathbf{C}-\boldsymbol{F}$, Calcium mobilization and area under the curve (AUC) measurements in HEK293 cells expressing mouse TNAP, Gqs, and either human $A_{2 B}$ R or no receptor (NR). Cells were stimulated with adenosine (AD0, $1 \mathrm{~mm}$, black) or AMP (1 mM) in the absence $(\boldsymbol{C}, \boldsymbol{D})$ or presence $(\boldsymbol{E}, \boldsymbol{F})$ of the TNAP inhibitor MLS-0038949 $(50 \mu \mathrm{m}$; added $40 \mathrm{~s}$ before stimulation and during stimulation). AUC measurements extended $1 \mathrm{~min}$ from agonist addition. Paired $t$ tests were used to compare the AUC data. Asterisks indicate a statistically significant difference when compared with ADO condition $\left({ }^{* * *} p<0.0005\right)$. All data are the average of two experiments performed in duplicate ( $n=20-58$ cells per condition).

$5 A, B, E, F)$. This membrane staining was eliminated when sections were incubated with the TNAP inhibitor MLS-0038949 (Fig. $5 C, D, G, H$ ), revealing that this staining originated from TNAP activity.

In addition, AMP histochemical staining was greatly reduced in spinal cord sections from dKO mice at $\mathrm{pH} 7.0$ (relative to WT mice), as we found previously (Street et al., 2011), and at $\mathrm{pH} 8.5$ (Fig. 6A, B,E,F). At $\mathrm{pH} 8.5$, weak AMP histochemical staining was still present in a broad region of the dorsal horn and on blood vessels of $\mathrm{dKO}$ mice (Fig. $6 F$ ). This residual staining was eliminated in the presence of MLS-0038949 (Fig. $6 \mathrm{H}$ ), indicating that it originated from TNAP activity. We obtained similar AMP histochemical results with WT and $\mathrm{dKO}$ slices in the presence and absence of the nonselective alkaline phosphatase inhibitor levamisole ( $5 \mathrm{~mm}$; data not shown). These experiments indicate that TNAP, PAP, and NT5E account for most if not all extracellular/membrane-delimited AMP hydrolytic activity in DRG and spinal cord.

We were unable to use adult Tnap ${ }^{-1-}$ mice for experiments because these mice die shortly after birth (Waymire et al., 1995; Narisawa et al., 1997). Instead, we resorted to using early postnatal Tnap ${ }^{-1-}$ mice. To confirm that genetic deletion of Tnap was equivalent to pharmacological inhibition of TNAP, we performed AMP histochemistry with DRG and spinal cord tissue from young (11-d-old) WT and Tnap ${ }^{-1-}$ mice at $\mathrm{pH} 8.5$ (Fig. 7). 


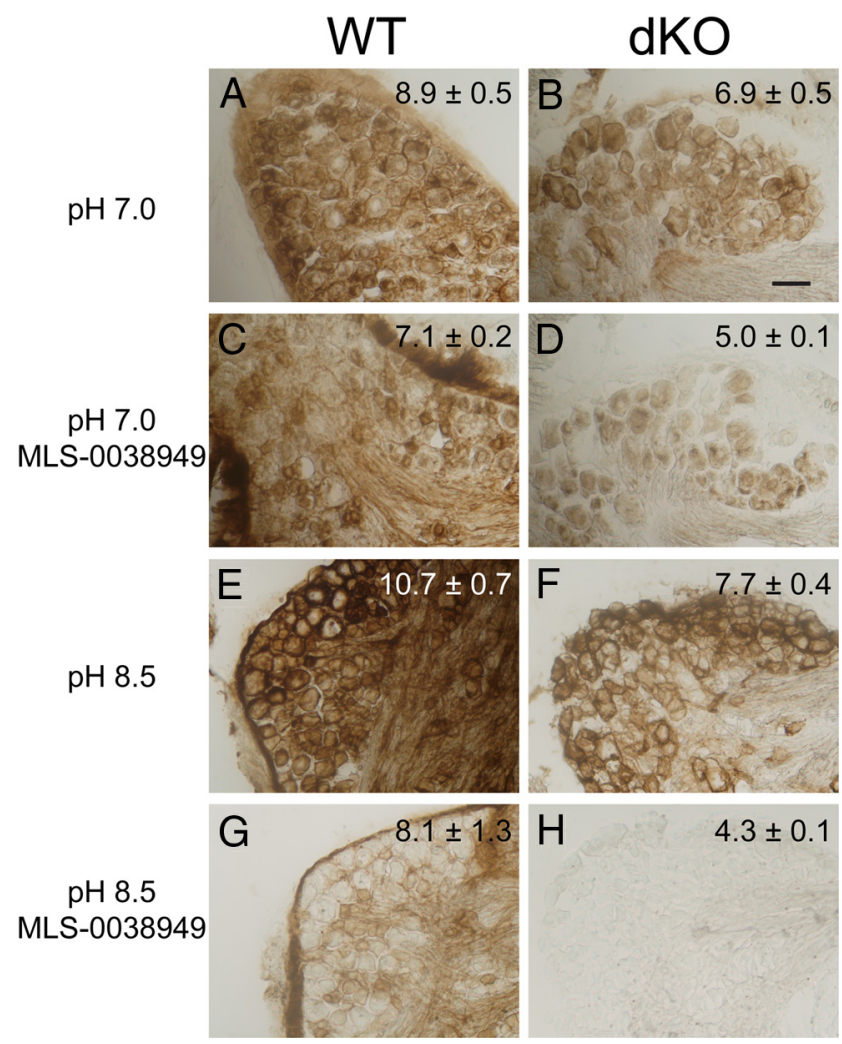

Figure 5. MLS-0038949 inhibits AMP hydrolytic activity in DRG from WT and dKO adult mice. DRG sections from WT $(\boldsymbol{A}, \boldsymbol{C}, \boldsymbol{E}, \boldsymbol{G})$ and dKO $(\boldsymbol{B}, \boldsymbol{D}, \boldsymbol{F}, \boldsymbol{H})$ mice were stained using AMP histochemistry at pH $7.0(\boldsymbol{A}-\boldsymbol{D})$ or pH $8.5(\boldsymbol{E}-\boldsymbol{H})$ in the absence or presence of MLS-0038949 (50 $\mu \mathrm{M})$. AMP concentration was $1 \mathrm{~mm}$. Similar results were obtained from $n=3$ mice from each genotype. Scale bar, $50 \mu \mathrm{m}$. Staining intensity was quantified as described in the Materials and Methods and reported (upper right) as mean \pm SEM. Repeated measures one-way ANOVA and Bonferroni's post hoc tests were used to compare staining intensity between genotypes. The only significant decrease in staining intensity at $\mathrm{pH} 7.0$ was found when comparing WT tissue with dKO tissue in the presence of MLS-0038949 ( $p<0.0005)$. At pH 8.5, sections from dKO mice in the presence of MLS-00038949 showed significantly less staining $(p<0.005)$ than sections from WT mice \pm MLS-0038949.

We found that AMP histochemical staining was greatly reduced throughout Tnap ${ }^{-1-}$ DRG compared with DRG from WT littermates (Fig. $7 A, B$ ), further demonstrating that TNAP was present and capable of hydrolyzing AMP in virtually all DRG neurons. Likewise, AMP histochemical staining that was present throughout the spinal cord gray matter of WT mice (Fig. 7C) was eliminated in Tnap ${ }^{-1-}$ spinal cord with the exception of the dorsal horn (Fig. 7D; analogous to what we observed when TNAP was pharmacologically inhibited, as shown in Fig. 6G). This residual AMP histochemical activity in Tnap ${ }^{-1-}$ dorsal horn was eliminated when sections were incubated with L-tartrate, an inhibitor of PAP, and $\alpha \beta$-methylene ADP ( $\alpha \beta$-me-ADP), an inhibitor of NT5E (Fig. $7 E, F$; analogous to what we observed when Pap and $\mathrm{Nt} 5 \mathrm{e}$ were genetically eliminated, as shown in Fig. $6 \mathrm{~F}, \mathrm{H}$ ). Therefore, using two independent methods to inhibit TNAP (one genetic and one pharmacological), we found that TNAP, PAP, and NT5E redundantly hydrolyzed AMP in DRG neurons and dorsal spinal cord.

We recently used FSCV to quantify adenosine concentration with subsecond resolution in the spinal microdomain (lamina II) where PAP and NT5E are located (Street et al., 2011). FSCV can be used to detect adenosine based on a $1.0 \mathrm{~V}$ oxidation peak that is specific to adenosine but not nucleotides (Swamy and Venton,

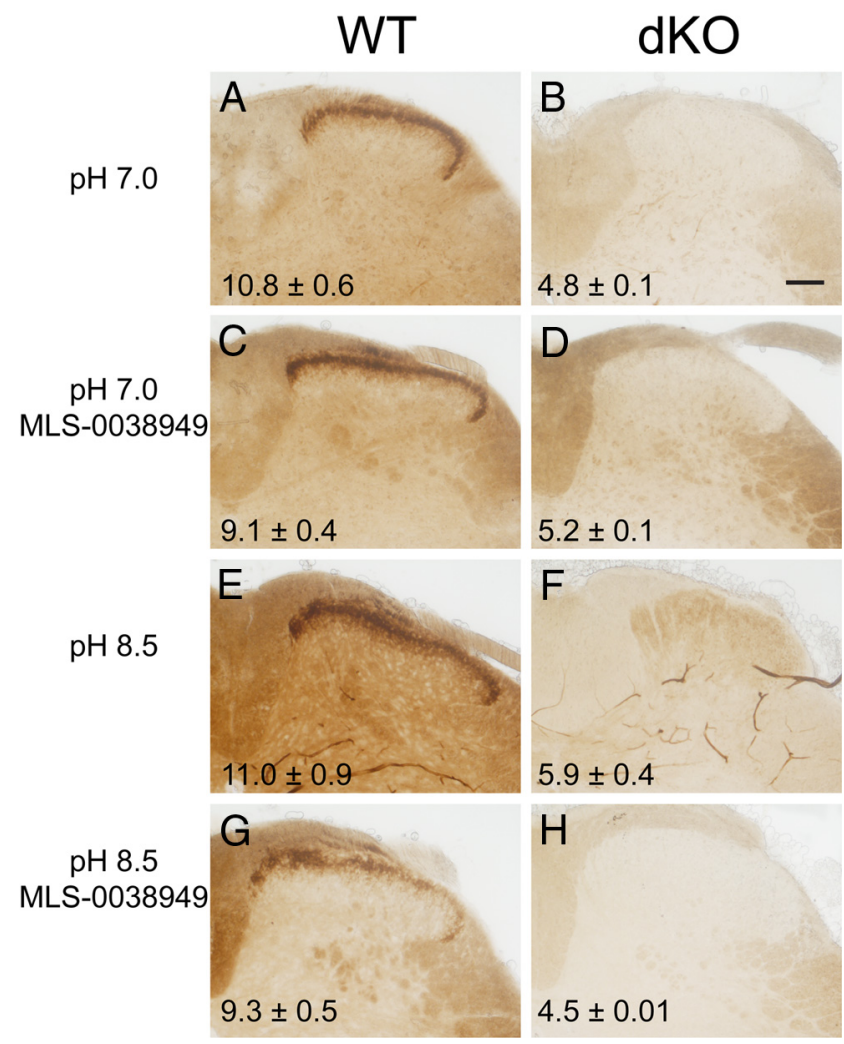

Figure 6. MLS-0038949 inhibits AMP hydrolytic activity in spinal cord from WT and dKO adult mice. Spinal cord sections from WT $(\boldsymbol{A}, \boldsymbol{C}, \boldsymbol{E}, \boldsymbol{G})$ and $\mathrm{dKO}(\boldsymbol{B}, \boldsymbol{D}, \boldsymbol{F}, \boldsymbol{H})$ mice were stained using AMP histochemistry at pH $7.0(\boldsymbol{A}-\boldsymbol{D})$ or $\mathrm{pH} 8.5(\boldsymbol{E}-\boldsymbol{H})$ in the absence or presence of MLS$0038949(50 \mu \mathrm{M})$. The AMP concentration was $3 \mathrm{~mm}$. Similar results were obtained from $n=3$ mice from each genotype. Scale bar, $200 \mu \mathrm{m}$. Staining intensity was quantified as described in the Materials and Methods and is reported (bottom left) as mean \pm SEM. Repeated-measures one-way ANOVA and Bonferroni's post hoc tests were used to compare staining intensity between genotypes. Slices from dKO mice (pH 7.0 and 8.5) in the presence of MLS-00038949 showed significantly less staining $(p<0.0005)$ than in tissue from WT mice ( $p H 7.0$ and 8.5$)$ in the presence or absence of MLS-00038949. There were no statistically significant decreases in staining intensity when comparing tissue from dKO mice in the presence or absence of MLS00038949 at pH 7.0 and 8.5 .

2007). In our previous study, we found that peak adenosine production (after pressure ejection of $100 \mu \mathrm{M}$ AMP into lamina II) was reduced by $>50 \%$ in spinal cord slices from dKO mice, to $\sim 1.5 \mu \mathrm{M}$ adenosine (Street et al., 2011). This concentration is similar to the $\mathrm{EC}_{50}$ of adenosine at $\mathrm{A}_{1} \mathrm{R}(1.4 \mu \mathrm{M}$; Rittiner et al., 2012) and therefore should be sufficient to activate $A_{1} R$ even though PAP and NT5E were genetically deleted.

To determine whether TNAP generates adenosine in lamina II, we used FSCV to quantify adenosine production in spinal cord slices from WT and dKO mice ( \pm MLS-0038949). We found that adenosine production was reduced by $>50 \%$ when $100 \mu \mathrm{M}$ AMP was pressure ejected onto lamina II of dKO mice (Fig. $8 A, B, E, F$ ), replicating our previous finding (Street et al., 2011). Inhibition of TNAP in WT slices (by adding MLS-0038949 to the bath) did not reduce adenosine production (Fig. $8 C, E, F$ ), analogous to our previous results showing that deletion of PAP alone did not reduce adenosine generation at neutral $\mathrm{pH}$ (Street et al., 2011). However, the addition of MLS-0038949 to the bath significantly reduced peak and sustained adenosine production in dKO slices to $<1 \mu \mathrm{M}$ (Fig. $8 D-F$ ), highlighting that simultaneous inhibition of TNAP, PAP, and NT5E is required to reduce adenosine production to near baseline levels in spinal lamina II. Moreover, these experiments revealed that TNAP, PAP, and NT5E redun- 


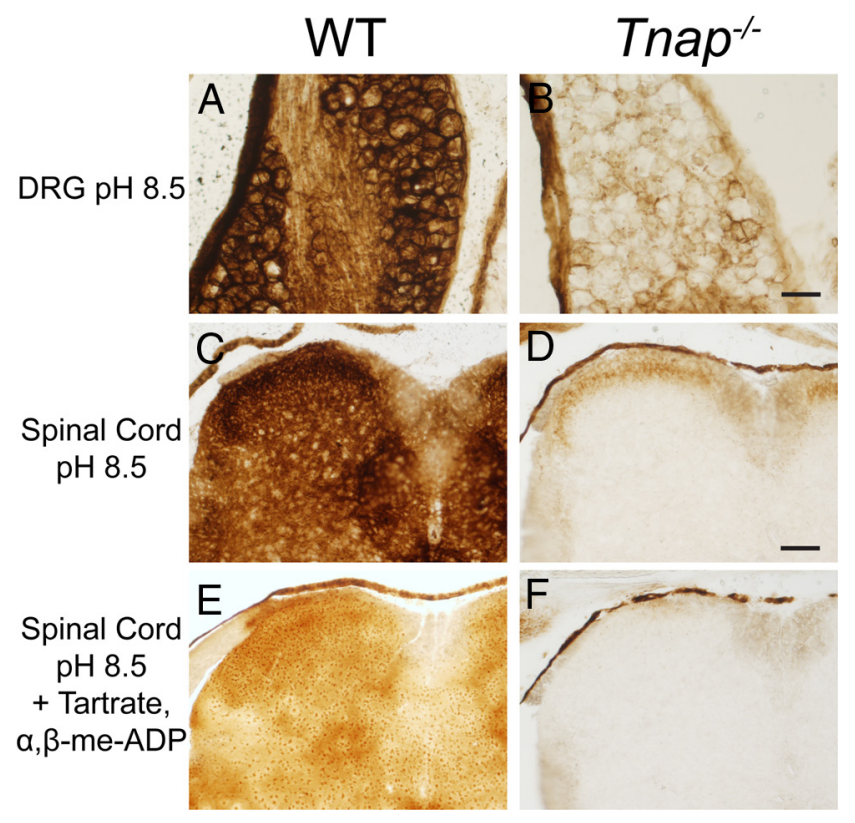

Figure 7. AMP histochemistry in DRG and spinal cord from Tnap ${ }^{-1-}$ mice. DRG $(\boldsymbol{A}, \boldsymbol{B})$ and spinal cord $(\boldsymbol{C}-\boldsymbol{F})$ sections from WT $(\boldsymbol{A}, \boldsymbol{C}, \boldsymbol{E})$ and Tnap $^{-1-}(\boldsymbol{B}, \boldsymbol{D}, \boldsymbol{F})$ mice were stained using AMP histochemistry at $\mathrm{pH}$ 8.5. The AMP concentration was $3 \mathrm{~mm} . \boldsymbol{E}, \boldsymbol{F}, \mathrm{AMP}$ histochemistry at $\mathrm{pH}$ 8.5 in the presence of L-tartrate $(20 \mathrm{~mm})$ to inhibit PAP and $\alpha \beta$-me-ADP $(10 \mu \mathrm{m})$ to inhibit NT5E. Tissue was obtained from 11-d-old mice (WT, $n=3$; Tnap $^{-1-}, n=3$ ).

dantly and rapidly generate most if not all adenosine from extracellular AMP in dorsal spinal cord.

\section{AMP inhibits excitatory neurotransmission in spinal cord, but does not inhibit neurotransmission when TNAP, PAP, and NT5E are inhibited simultaneously}

Adenosine inhibits synaptic transmission in the dorsal spinal cord by activating $A_{1} R$ on primary somatosensory afferents (presynaptically) and on spinal neurons (postsynaptically; Li and Perl, 1994; Lao et al., 2001). In addition, AMP has long been known to inhibit neurons in the dorsal spinal cord (Salter and Henry, 1985), although whether this reflects direct activation of adenosine receptors by AMP (Rittiner et al., 2012) or indirect activation via ectonucleotidases that hydrolyze AMP to adenosine is unknown. Given that we could now inhibit the three main AMP ectonucleotidases that are present in dorsal spinal cord, we next sought to resolve this longstanding issue while also assessing the extent to which TNAP regulates spinal neurotransmission by generating adenosine. To accomplish these goals, we assessed how AMP and adenosine (each bath applied at $250 \mu \mathrm{M}$ ) affected field EPSPs (fEPSPs) in spinal cord slices when zero, one, two, or all three AMP ectonucleotidases were inactivated.

First, we found that AMP and adenosine reduced fEPSP amplitude in lamina II of WT slices by $\sim 50 \%$ (Fig. $9 A a, A b, B$ ), highlighting that AMP and adenosine were equally effective at reducing excitatory neurotransmission. This inhibitory effect on neurotransmission was entirely dependent on $\mathrm{A}_{1} \mathrm{R}$ activation, because AMP and adenosine did not inhibit fEPSP amplitude in slices from $A_{1} R^{-1-}$ mice (Fig. $9 B$ ).

To determine whether this inhibitory effect of AMP required PAP and/or NT5E, we quantified fEPSP amplitude in response to AMP and adenosine in spinal cord slices from WT, Pap ${ }^{-1-}$, $N t 5 e^{-1-}$, and $\mathrm{dKO}$ mice. We found that AMP and adenosine were equally effective at inhibiting fEPSPs in all of these geno-
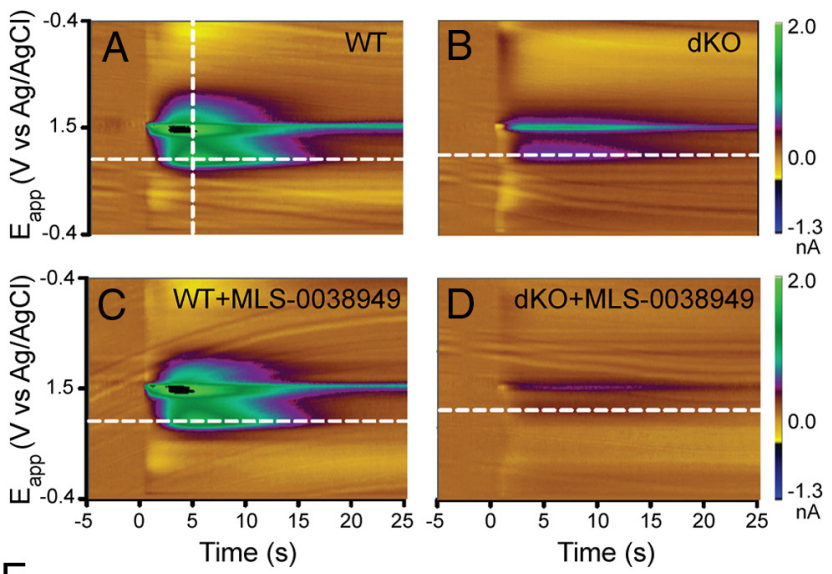

E
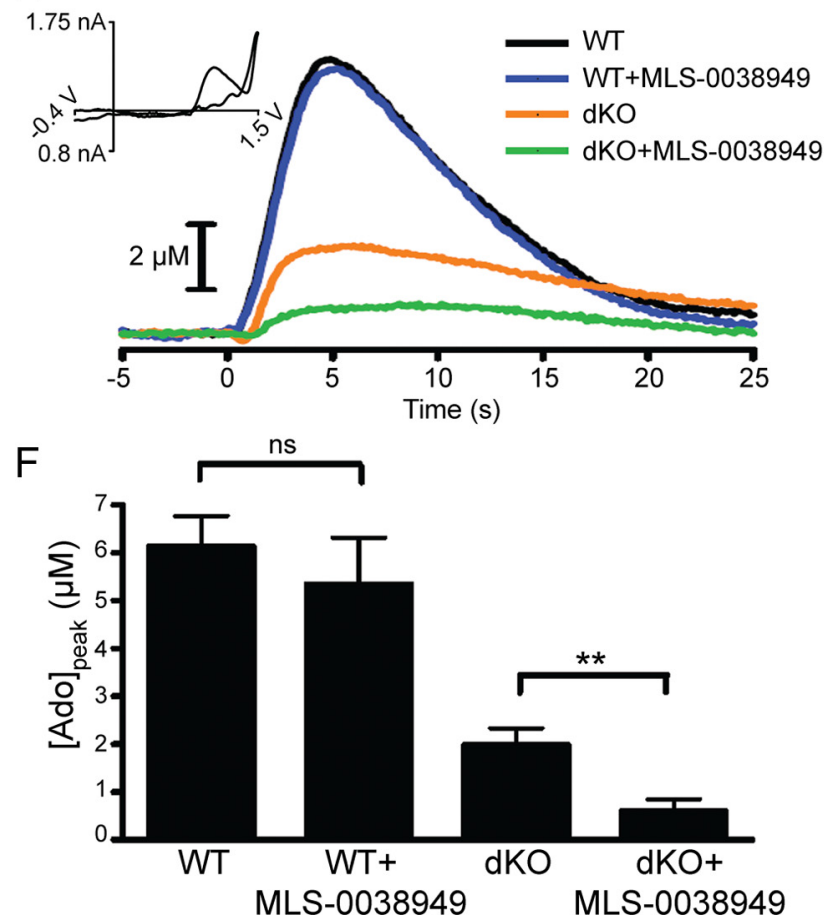

Figure 8. Triple inhibition of TNAP, PAP, and NT5E virtually eliminates hydrolysis of AMP to adenosine in spinal lamina II. FSCV was used to measure adenosine production at subsecond resolution. $\boldsymbol{A}-\boldsymbol{D}, \mathrm{FSCV}$ color plots: $100 \mu \mathrm{m}$ AMP was pressure ejected for 1 s onto lamina ll of WT $(\boldsymbol{A}, \boldsymbol{C})$ or dKO $(\boldsymbol{B}, \boldsymbol{D})$ mice in the absence or presence of MLS-0038949 $(50 \mu \mathrm{M})$. $\boldsymbol{E}$, Adenosine concentration calculated from $1.0 \mathrm{~V}$ current (dashed horizontal lines in $\boldsymbol{A}-\boldsymbol{D}$ ). Inset: (yclic voltammogram confirms that adenosine was produced (plotted from dashed vertical line in $\boldsymbol{A}$ ). $\boldsymbol{F}$, Peak adenosine concentration after pressure ejecting AMP onto lamina II ( $n=5$ slices for each condition). $t$ tests were used for comparisons. ${ }^{* *} p<0.005$.

types (Fig. 9C), suggesting that a third AMP hydrolytic enzyme was active in this physiological preparation.

To determine whether TNAP was this third ectonucleotidase,

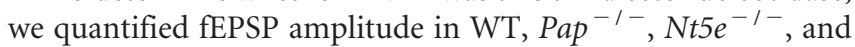
$\mathrm{dKO}$ slices that were incubated with the TNAP-specific inhibitor MLS-0038949. We found that AMP and adenosine were equally effective at inhibiting fEPSPs in slices from WT mice and $\mathrm{Pap}{ }^{-1-}$ mice that were incubated with MLS-0038949 (Fig. 9D, E). In contrast, AMP was significantly less effective at inhibiting fEPSPs in $N t 5 e^{-1-}$ slices in the presence of MLS-0038949, although the inhibitory effect of AMP was not eliminated (Fig. 9D; AMP still significantly reduced fEPSP amplitude relative to baseline). Remarkably, the inhibitory effect of AMP was lost only when all three ectonucleotidases (TNAP, PAP, and NT5E) were inhibited 
(Fig. 9E; adenosine remained effective under all conditions). These data strongly suggest that all three enzymes are capable of hydrolyzing AMP to adenosine and facilitate inhibition of excitatory neurotransmission through $A_{1} R$ activation. With our unprecedented genetic and pharmacological control over these enzymes, we were able to show that TNAP, PAP, and NT5E are triply redundant in the dorsal spinal cord. In addition, our data strongly support the indirect (ectonucleotidase-dependent) model in which the biological effects of extracellular AMP are mediated via hydrolysis to adenosine. Indeed, adenosine concentration fell below the $\mathrm{EC}_{50}$ of $\mathrm{A}_{1} \mathrm{R}$ only when all three enzymes were deleted/inhibited (Fig. 8F).

Last, to determine whether Tnap expression in DRG changed when Pap and/or Nt5e were deleted, we measured Tnap mRNA levels in WT, Pap ${ }^{-1-}$, $N t 5 e^{-1-}$, and dKO mice using quantitative RT-PCR. We found that Tnap mRNA levels did not change relative to WT in any of the knock-out lines (Fig. $9 F$ ), ruling out the possibility that Tnap expression compensated for the loss/deletion of other AMP ectonucleotidases.

\section{Discussion}

Nucleotides and nucleosides play key roles in pain signaling and sensory biology. ATP, acting through purinergic receptors, can sensitize DRG neurons and cause longlasting thermal hyperalgesia and mechanical allodynia (Nakagawa et al., 2007; Sowa et al., 2010c) and adenosine has antinociceptive effects (Sawynok, 2007; Zylka, 2011). We previously identified PAP and NT5E as two ectonucleotidases that generate extracellular adenosine from AMP and found that both enzymes play important roles in nociceptive physiology (Zylka et al., 2008; Sowa et al., 2010a). Although AMP hydrolysis was reduced when each of these enzymes was deleted alone or in combination, we were surprised that AMP hydrolytic activity was not eliminated, suggesting the existence of at least one more AMP ectonucleotidase in DRG neurons and/or dorsal spinal cord (Street et al., 2011).

In our present study, we found that TNAP is widely expressed in DRG neurons and spinal cord and can dephosphorylate AMP in these tissues. These findings were based on our use of three different assays: enzyme histochemistry, quantitative FSCV, and slice electrophysiology. Although TNAP, PAP, and NT5E collectively account for most if not all AMP ectonucleotidase activity in sensory circuits, we cannot formally exclude the possibility that an additional AMP ectonucleotidase is present, particularly because a small amount of adenosine was generated in FSCV experiments when TNAP, PAP, and NT5E were all inhibited (Fig. $8 F$ ). However, the concentration of this residual adenosine was below the $\mathrm{EC}_{50}$ for $\mathrm{A}_{1} \mathrm{R}$ activation and was not sufficient to inhibit neurotransmission (Fig. 9E), suggesting that this residual adeno-

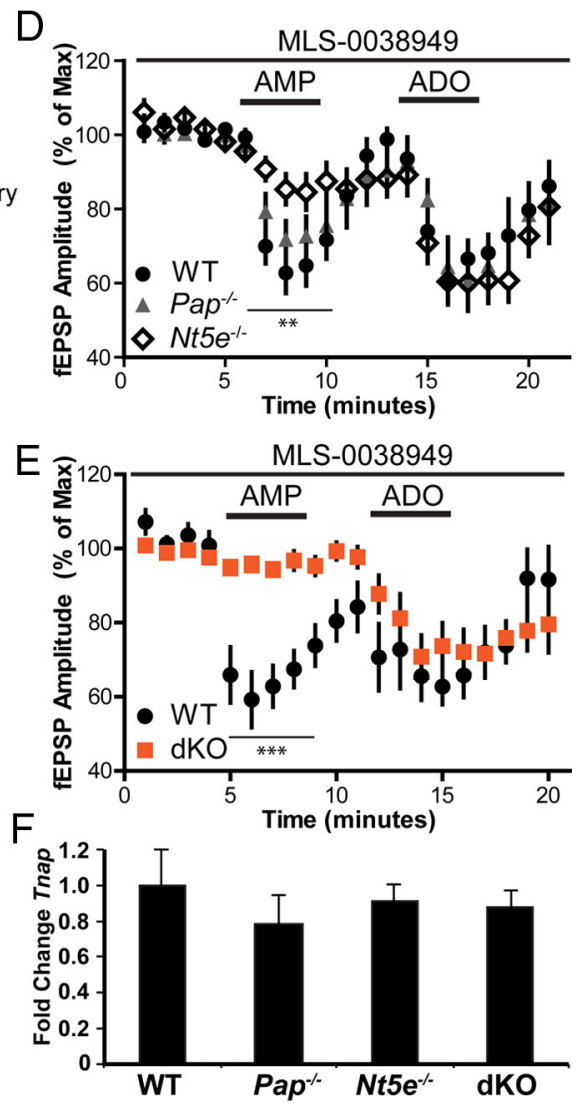

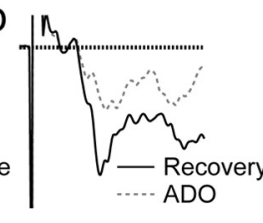

ADO
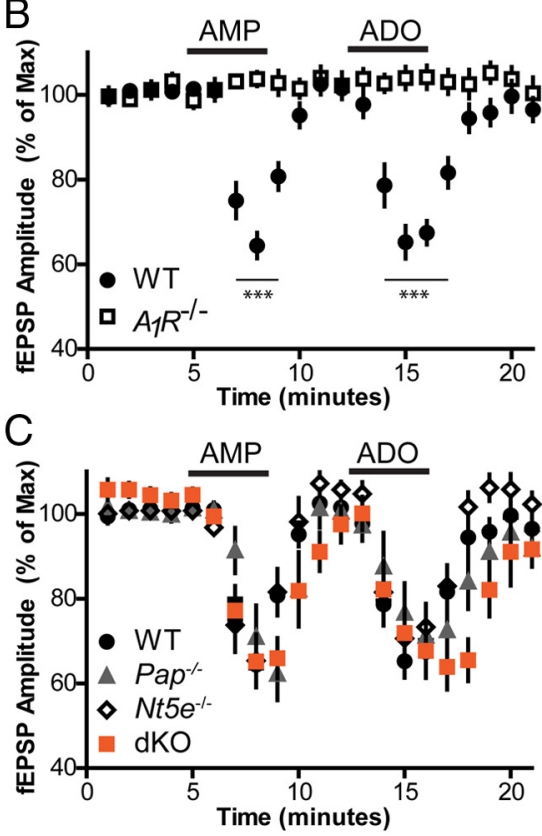

Figure 9. AMP inhibits excitatory neurotransmission in lamina ll of WT, $\mathrm{Pap}^{-I^{-}}, \mathrm{Nt} 5 \mathrm{e}^{-I-}$, and dKO mice but not after triple

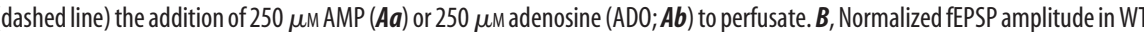
spinal cord slices ( $n=25$ and 11, respectively). $t$ tests were used to compare fEPSP amplitude in WT and $A_{1} R$ ( $n=25,10,20$, and 16, respectively). No significant differences were found between genotypes using one-way ANOVA followed

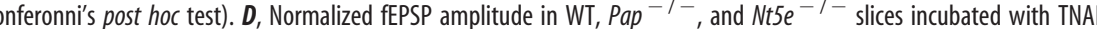

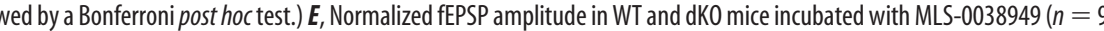
and 12 , respectively). $t$ tests were used to compare WT with dKO responses at each time point. ${ }^{* *} p<0.0005$. $F$, Genetic deletion of Pap and/or Nt5e does not change the expression of Tnap mRNA. Tnap expression levels were measured in DRG from Pap ${ }^{-1-}$ $N t 5 e^{-1-}$, and dKO mice by quantitative RT-PCR. Results are given as arbitrary units, normalized to expression of $\beta$-actin. № significant differences were observed between genotypes (one-way ANOVA $\alpha=0.05, p=0.77, n=3$ for each genotype).

sine had no discernible impact on neuronal physiology. Because this residual adenosine was first detected several seconds after pressure ejecting AMP instead of immediately afterward, the residual adenosine is likely of enzymatic origin rather than being present in the AMP stock solution. One possibility is that this residual adenosine originates from TNAP (e.g., if MLS-0038949 did not fully penetrate into the slice preparation and fully inhibit TNAP or if MLS-0038949 reversibly interacts with TNAP-indeed, MLS-0038949 is an uncompetitive inhibitor of TNAP [Kiffer-Moreira et al., 2013] and its binding is reversible).

Our research now resolves a longstanding ( $>40$ years) question in the somatosensory field: what are the molecular identities of the enzymes that hydrolyze extracellular AMP to adenosine in dorsal spinal cord? (Fieschi and Soriani, 1959; Scott, 1967). Our experiments indicate that TNAP, PAP, and NT5E are each capable of hydrolyzing AMP to adenosine in spinal lamina II and that each enzyme inhibits spinal circuit excitability by generating adenosine and activating $\mathrm{A}_{1} \mathrm{R}$. Note that PAP and NT5E are localized to lamina II, whereas TNAP is more broadly distributed in 
the dorsal horn and throughout spinal cord, consistent with TNAP being found in nociceptive and nonnociceptive regions of spinal cord. Our results support a major role for TNAP, PAP, and NT5E in regulating extracellular adenosine concentration, extracellular nucleotide metabolism, and neurophysiology in primary somatosensory neurons and spinal cord.

Intriguingly, the somatosensory system is not the only location where TNAP functions redundantly. Indeed, TNAP is often coexpressed with other ectonucleotidases (Zimmermann, 2006a; Langer et al., 2008) and redundantly generates adenosine from extracellular AMP in the hippocampus, including when $N t 5 e$ is deleted (Zhang et al., 2012). The importance of TNAP in generating adenosine in the nervous system has been underappreciated, but clearly should be considered in future studies and when interpreting previous studies that did not control for TNAP activity (Dunwiddie et al., 1997; Klyuch et al., 2012; Lovatt et al., 2012). This is particularly important when using physiological readouts because inhibition of TNAP alone, PAP alone, NT5E alone, or any pairwise combination (TNAP and PAP; TNAP and NT5E; PAP and NT5E) was not sufficient to block AMP hydrolysis to adenosine or to block maximal inhibition of neurotransmission by a nucleotide (Fig. 9C; Zhang et al., 2012). We can only speculate as to why the nervous system contains redundant enzymes that generate adenosine. Such redundancy could reflect the fact that there are activity-dependent changes in extracellular $\mathrm{pH}$, including in the spinal dorsal horn (Syková and Svoboda, 1990), that necessitate multiple enzymes for efficient extracellular nucleotide metabolism and recycling.

Previously, we found that thermal and mechanical sensitivity was enhanced in models of chronic pain when PAP or NT5E were deleted alone or in combination (Zylka et al., 2008; Sowa et al., 2010a). Tnap ${ }^{-1-}$ mice die shortly after birth (Waymire et al., 1995; Narisawa et al., 1997), making it impossible for us to assess how TNAP deletion affects nociceptive behaviors in adults. Moreover, lumbar nerve roots are smaller in Tnap ${ }^{-1-}$ neonates (Narisawa et al., 1997), suggesting that TNAP is required for somatosensory circuit development or maintenance. Experiments with Tnap conditional knock-out mice could be equally challenging, because it will likely be necessary to delete TNAP in adult DRG neurons and the spinal cord (i.e., to delete TNAP from somatosensory afferents and spinal neurons that are postsynaptic to somatosensory afferents).

We recently found that adenosine and AMP can activate $A_{1} R$ directly in cell lines and in neurons (Rittiner et al., 2012). However, our current data indicate that AMP does not inhibit neurotransmission via direct activation of $A_{1} R$ (as evidenced by the fact that AMP did not inhibit neurotransmission when all three ectonucleotidases were inhibited/deleted). This discrepancy immediately raises the question as to why AMP did not inhibit neurotransmission via direct effects on $A_{1} R$ when AMP (and a nonhydrolyzable AMP analog) activated $\mathrm{A}_{1} \mathrm{R}$ directly (independent of ectonucleotidase activity) in cell lines. Although we do not have a definitive explanation for this discrepancy, we speculate that this is due to functional selectivity of $A_{1} R$ ligands (Verzijl and Ijzerman, 2011). Functional selectivity refers to the ability of ligands to preferentially activate a subset of signal transduction pathways that are downstream of a given receptor.

$A_{1} R$ is classically considered to be a Gi/Go-coupled receptor and to inhibit adenylate cyclase. In our previous study, we exclusively monitored Gi-coupled signaling in cells to demonstrate that AMP can activate $A_{1} R$ directly (Rittiner et al., 2012). However, $A_{1} R$ also couples to other downstream mediators, including $\beta$-arrestin (and downstream kinases) and phospholipase C (via
G $\beta \gamma$ subunits; Verzijl and Ijzerman, 2011). It is increasingly clear that $\mathrm{A}_{1} \mathrm{R}$ displays functional selectivity. A 5 '-modified adenosine analog (LUF5589) was shown to preferentially activate the Gi pathway downstream of $A_{1} R$, whereas the parent compound lacking the $5^{\prime}$ modification (MRS542) activated both the Gi and $\beta$-arrestin pathways (Langemeijer et al., 2013). Likewise, a different $5^{\prime}$-modified agonist (CPeCA) preferentially activated the $\mathrm{Gi}$ and the $G$ s pathways downstream of $A_{1} R$, whereas the parent compound lacking a bulky group at the $5^{\prime}$ position (NECA) activated Gi, Gs, and phospolipase C pathways (Cordeaux et al., 2004). Future studies will be needed to ascertain whether AMP and other AMP analogs are functionally selective ligands for $A_{1} R$ and if this functional selectivity prevents AMP from affecting physiology or nociceptive behavior directly. Our current data and previously published data argue that the physiological and in vivo effects of AMP are indirect. For example, we previously found that the in vivo antinociceptive effects of AMP were dependent on ectonucleotidases (Street et al., 2011).

Last, our current findings have clinical implications, particularly given our previous work showing that purified versions of PAP and NT5E protein have long-lasting (2-6 d) $A_{1} R$-dependent antinociceptive effects when injected intrathecally or peripherally (Zylka et al., 2008; Sowa et al., 2009; Sowa et al., 2010b; Hurt and Zylka, 2012). Intrathecal injection of placental alkaline phosphatase did not have an acute thermal antinociceptive effect in mice (Zylka et al., 2008). However, placental alkaline phosphatase is not TNAP. A recombinant version of TNAP synthesized with a bone-homing fusion tag (Millán et al., 2008) was recently found to heal rickets in patients with hypophosphatasia without adverse drug-related events (Whyte et al., 2012). This remarkable study highlights the therapeutic potential of enzyme replacement therapy in the setting of a chronic disorder and, more generally, the therapeutic utility and safety profile of a recombinant enzyme/ ectonucleotidase in humans. Ultimately, it should be possible to assess the antinociceptive effects of TNAP in preclinical models of chronic pain once a suitable recombinant version of TNAP is available (such as one lacking a bone-homing peptide).

\section{References}

Ciancaglini P, Yadav MC, Simão AM, Narisawa S, Pizauro JM, Farquharson C, Hoylaerts MF, Millán JL (2010) Kinetic analysis of substrate utilization by native and TNAP-, NPP1-, or PHOSPHO1-deficient matrix vesicles. J Bone Miner Res 25:716-723. CrossRef Medline

Cordeaux Y, Ijzerman AP, Hill SJ (2004) Coupling of the human A1 adenosine receptor to different heterotrimeric $G$ proteins: evidence for agonist-specific G protein activation. Br J Pharmacol 143:705-714. CrossRef Medline

Dahl R, Sergienko EA, Su Y, Mostofi YS, Yang L, Simao AM, Narisawa S, Brown B, Mangravita-Novo A, Vicchiarelli M, Smith LH, O’Neill WC, Millán JL, Cosford ND (2009) Discovery and validation of a series of aryl sulfonamides as selective inhibitors of tissue-nonspecific alkaline phosphatase (TNAP). J Med Chem 52:6919-6925. CrossRef Medline

Díez-Zaera M, Díaz-Hernández JI, Hernández-Álvarez E, Zimmermann H, Díaz-Hernández M, Miras-Portugal MT (2011) Tissue-nonspecific alkaline phosphatase promotes axonal growth of hippocampal neurons. Mol Biol Cell 22:1014-1024. CrossRef Medline

Dong X, Han S, Zylka MJ, Simon MI, Anderson DJ (2001) A diverse family of GPCRs expressed in specific subsets of nociceptive sensory neurons. Cell 106:619-632. CrossRef Medline

Dunwiddie TV, Diao L, Proctor WR (1997) Adenine nucleotides undergo rapid, quantitative conversion to adenosine in the extracellular space in rat hippocampus. J Neurosci 17:7673-7682. Medline

Fieschi C, Soriani F (1959) Enzymatic activities in the spinal cord after sciatic section: alkaline and acid phosphatases, $5^{\prime}$-nucleotidase and ATP-ase. J Neurochem 4:71-77. CrossRef Medline

Fonta C, Négyessy L, Renaud L, Barone P (2004) Areal and subcellular localization of the ubiquitous alkaline phosphatase in the primate cerebral 
cortex: evidence for a role in neurotransmission. Cereb Cortex 14:595609. CrossRef Medline

Hurt JK, Zylka MJ (2012) PAPupuncture has localized and long-lasting antinociceptive effects in mouse models of acute and chronic pain. Mol Pain 8:28. CrossRef Medline

Kiffer-Moreira T, Yadav MC, Zhu D, Narisawa S, Sheen C, Stec B, Cosford ND, Dahl R, Farquharson C, Hoylaerts MF, Macrae VE, Millán JL (2013) Pharmacological inhibition of PHOSPHO1 suppresses vascular smooth muscle cell calcification. J Bone Miner Res 28:81-91. CrossRef Medline

Klyuch BP, Dale N, Wall MJ (2012) Deletion of ecto-5'-nucleotidase (CD73) reveals direct action potential-dependent adenosine release. J Neurosci 32:3842-3847. CrossRef Medline

Langemeijer EV, Verzijl D, Dekker SJ, Ijzerman AP (2013) Functional selectivity of adenosine A(1) receptor ligands? Purinergic Signal 9:91-100. CrossRef Medline

Langer D, Hammer K, Koszalka P, Schrader J, Robson S, Zimmermann H (2008) Distribution of ectonucleotidases in the rodent brain revisited. Cell Tissue Res 334:199-217. CrossRef Medline

Lao LJ, Kumamoto E, Luo C, Furue H, Yoshimura M (2001) Adenosine inhibits excitatory transmission to substantia gelatinosa neurons of the adult rat spinal cord through the activation of presynaptic $\mathrm{A}(1)$ adenosine receptor. Pain 94:315-324. CrossRef Medline

Li J, Perl ER (1994) Adenosine inhibition of synaptic transmission in the substantia gelatinosa. J Neurophysiol 72:1611-1621. Medline

Lovatt D, Xu Q, Liu W, Takano T, Smith NA, Schnermann J, Tieu K, Nedergaard M (2012) Neuronal adenosine release, and not astrocytic ATP release, mediates feedback inhibition of excitatory activity. Proc Natl Acad Sci U S A 109:6265-6270. CrossRef Medline

MacGregor GR, Zambrowicz BP, Soriano P (1995) Tissue non-specific alkaline phosphatase is expressed in both embryonic and extraembryonic lineages during mouse embryogenesis but is not required for migration of primordial germ cells. Development 121:1487-1496. Medline

Millán JL (2006a) Mammalian alkaline phosphatases: from biology to applications in medicine and biotechnology. Weinheim, Germany: WileyVCH Verlag.

Millán JL (2006b) Alkaline Phosphatases: Structure, substrate specificity and functional relatedness to other members of a large superfamily of enzymes. Purinergic Signal 2:335-341. CrossRef Medline

Millán JL, Narisawa S, Lemire I, Loisel TP, Boileau G, Leonard P, Gramatikova S, Terkeltaub R, Camacho NP, McKee MD, Crine P, Whyte MP (2008) Enzyme replacement therapy for murine hypophosphatasia. J Bone Miner Res 23:777-787. CrossRef Medline

Mornet E (2007) Hypophosphatasia. Orphanet J Rare Dis 2:40. CrossRef Medline

Nakagawa T, Wakamatsu K, Zhang N, Maeda S, Minami M, Satoh M, Kaneko S (2007) Intrathecal administration of ATP produces long-lasting allodynia in rats: differential mechanisms in the phase of the induction and maintenance. Neuroscience 147:445-455. CrossRef Medline

Narisawa S, Hasegawa H, Watanabe K, Millán JL (1994) Stage-specific expression of alkaline phosphatase during neural development in the mouse. Dev Dyn 201:227-235. CrossRef Medline

Narisawa S, Fröhlander N, Millán JL (1997) Inactivation of two mouse alkaline phosphatase genes and establishment of a model of infantile hypophosphatasia. Dev Dyn 208:432-446. CrossRef Medline

Picher M, Burch LH, Hirsh AJ, Spychala J, Boucher RC (2003) Ecto 5'-nucleotidase and nonspecific alkaline phosphatase. Two AMP-hydrolyzing ectoenzymes with distinct roles in human airways. J Biol Chem 278:13468-13479. CrossRef Medline

Rittiner JE, Korboukh I, Hull-Ryde EA, Jin J, Janzen WP, Frye SV, Zylka MJ (2012) AMP is an adenosine A1 receptor agonist. J Biol Chem 287:5301-5309. CrossRef Medline

Salter MW, Henry JL (1985) Effects of adenosine 5'-monophosphate and adenosine $5^{\prime}$-triphosphate on functionally identified units in the cat spinal dorsal horn: evidence for a differential effect of adenosine $5^{\prime}$ triphosphate on nociceptive vs non-nociceptive units. Neuroscience 15: 815-825. CrossRef Medline

Sawynok J (2007) Adenosine and ATP receptors. Handb Exp Pharmacol: 309-328. Medline

Scheibe RJ, Kuehl H, Krautwald S, Meissner JD, Mueller WH (2000) Ectoalkaline phosphatase activity identified at physiological $\mathrm{pH}$ range on intact P19 and HL-60 cells is induced by retinoic acid. J Cell Biochem 76:420-436. CrossRef Medline
Schetinger MR, Morsch VM, Bonan CD, Wyse AT (2007) NTPDase and 5 '-nucleotidase activities in physiological and disease conditions: new perspectives for human health. Biofactors 31:77-98. CrossRef Medline

Scott T (1967) The distribution of 5'-nucleotidase in the brain of the mouse. J Comp Neurol 129:97-114. CrossRef

Sergienko E, Su Y, Chan X, Brown B, Hurder A, Narisawa S, Millán JL (2009) Identification and characterization of novel tissue-nonspecific alkaline phosphatase inhibitors with diverse modes of action. J Biomol Screen 14:824-837. CrossRef Medline

Sowa NA, Vadakkan KI, Zylka MJ (2009) Recombinant mouse PAP has $\mathrm{pH}$-dependent ectonucleotidase activity and acts through $\mathrm{A}(1)$ adenosine receptors to mediate antinociception. PLoS One 4:e4248. CrossRef Medline

Sowa NA, Taylor-Blake B, Zylka MJ (2010a) Ecto-5'-nucleotidase (CD73) inhibits nociception by hydrolyzing AMP to adenosine in nociceptive circuits. J Neurosci 30:2235-2244. CrossRef Medline

Sowa NA, Voss MK, Zylka MJ (2010b) Recombinant ecto-5' -nucleotidase (CD73) has long lasting antinociceptive effects that are dependent on adenosine A1 receptor activation. Mol Pain 6:20. CrossRef Medline

Sowa NA, Street SE, Vihko P, Zylka MJ (2010c) Prostatic acid phosphatase reduces thermal sensitivity and chronic pain sensitization by depleting phosphatidylinositol 4,5-bisphosphate. J Neurosci 30:10282-10293. CrossRef Medline

St Hilaire C, Ziegler SG, Markello TC, Brusco A, Groden C, Gill F, CarlsonDonohoe H, Lederman RJ, Chen MY, Yang D, Siegenthaler MP, Arduino C, Mancini C, Freudenthal B, Stanescu HC, Zdebik AA, Chaganti RK, Nussbaum RL, Kleta R, Gahl WA, et al. (2011) NT5E mutations and arterial calcifications. N Engl J Med 364:432-442. CrossRef Medline

Street SE, Walsh PL, Sowa NA, Taylor-Blake B, Guillot TS, Vihko P, Wightman RM, Zylka MJ (2011) PAP and NT5E inhibit nociceptive neurotransmission by rapidly hydrolyzing nucleotides to adenosine. Mol Pain 7:80. CrossRef Medline

Swamy BE, Venton BJ (2007) Subsecond detection of physiological adenosine concentrations using fast-scan cyclic voltammetry. Anal Chem 79: 744-750. CrossRef Medline

Syková E, Svoboda J (1990) Extracellular alkaline-acid-alkaline transients in the rat spinal cord evoked by peripheral stimulation. Brain Res 512:181-189. CrossRef Medline

Thompson LF, Eltzschig HK, Ibla JC, Van De Wiele CJ, Resta R, MoroteGarcia JC, Colgan SP (2004) Crucial role for ecto-5'-nucleotidase (CD73) in vascular leakage during hypoxia. J Exp Med 200:1395-1405. CrossRef Medline

Van Etten RL (1982) Human prostatic acid phosphatase: a histidine phosphatase. Ann N Y Acad Sci 390:27-51. CrossRef Medline

Verzijl D, Ijzerman AP (2011) Functional selectivity of adenosine receptor ligands. Purinergic Signal 7:171-192. CrossRef Medline

Vihko P, Quintero I, Ronka AE, Herrala A, Jantti P, Porvari K, Lindqvist Y, Kaija H, Pulkka A, Vuoristo J (2005) Acid phosphatase (PAcP) is PI(3)Pphosphatase and its inactivation leads to change of the cell polarity and invasive prostate cancer. Proceedings of the AACR, 96th Annual Meeting. Anaheim, CA. Abstract 5239.

Waymire KG, Mahuren JD, Jaje JM, Guilarte TR, Coburn SP, MacGregor GR (1995) Mice lacking tissue non-specific alkaline phosphatase die from seizures due to defective metabolism of vitamin B-6. Nat Genet 11:45-51. CrossRef Medline

Whyte MP, Greenberg CR, Salman NJ, Bober MB, McAlister WH, Wenkert D, Van Sickle BJ, Simmons JH, Edgar TS, Bauer ML, Hamdan MA, Bishop N, Lutz RE, McGinn M, Craig S, Moore JN, Taylor JW, Cleveland RH, Cranley WR, Lim R, et al. (2012) Enzyme-replacement therapy in lifethreatening hypophosphatasia. N Engl J Med 366:904-913. CrossRef Medline

Wu WP, Hao JX, Halldner L, Lövdahl C, DeLander GE, Wiesenfeld-Hallin Z, Fredholm BB, Xu XJ (2005) Increased nociceptive response in mice lacking the adenosine A1 receptor. Pain 113:395-404. CrossRef Medline

Yadav MC, de Oliveira RC, Foster BL, Fong H, Cory E, Narisawa S, Sah RL, Somerman M, Whyte MP, Millán JL (2012) Enzyme replacement prevents enamel defects in hypophosphatasia mice. J Bone Miner Res 27: 1722-1734. CrossRef Medline

Zhang D, Xiong W, Chu S, Sun C, Albensi BC, Parkinson FE (2012) Inhibition of hippocampal synaptic activity by ATP, hypoxia or oxygen-glucose deprivation does not require CD73. PLoS One 7:e39772. CrossRef Medline 
Zimmermann H (2006a) Ectonucleotidases in the nervous system. Novartis Found Symp 2006;276:113-128; discussion 128-30, 233-7, 275-81. Medline

Zimmermann H (2006b) Nucleotide signaling in nervous system development. Pflugers Arch 452:573-588. CrossRef Medline

Zylka MJ (2011) Pain-relieving prospects for adenosine receptors and ectonucleotidases. Trends Mol Med 17:188-196. CrossRef Medline
Zylka MJ, Sowa NA, Taylor-Blake B, Twomey MA, Herrala A, Voikar V, Vihko P (2008) Prostatic acid phosphatase is an ectonucleotidase and suppresses pain by generating adenosine. Neuron 60:111-122. CrossRef Medline 